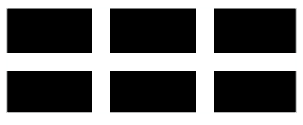

The WiLliam DAVIDSON Institute AT THE UNIVERSITY OF MICHIGAN BUSINESS SCHOOL

Does Foreign Direct Investment Increase the Productivity of Domestic Firms? In Search of Spillovers through Backward Linkages

\author{
By: Beata K. Smarzynska
}

William Davidson Working Paper Number 548

March 2003 


\title{
Does Foreign Direct Investment Increase the Productivity of Domestic Firms? In Search of Spillovers through Backward Linkages
}

\author{
Beata K. Smarzynska*
}

\begin{abstract}
Many countries aim to attract foreign direct investment (FDI) by offering ever more generous incentive packages and justifying their actions with the expected knowledge externalities to be generated by foreign affiliates. Despite being hugely important to public policy, there is little conclusive evidence to support this claim. This study examines firm-level data from Lithuania in an effort to further our understanding of this issue. The empirical results are consistent with positive productivity spillovers from FDI taking place through contacts between foreign affiliates and their local suppliers in upstream sectors, but there is no indication of spillovers occurring within the same industry. The data indicate that local firms benefit from the operation of foreign affiliates both in their own region and in other parts of the country, albeit the evidence of the latter outcome is weaker. A larger effect is associated with domestic-marketrather than export-oriented foreign companies. There is no difference, however, between the impact of fully-owned foreign firms and those with joint domestic and foreign ownership.
\end{abstract}

Keywords: spillovers, foreign direct investment, technology transfer

JEL classification: F23

\footnotetext{
* The World Bank, 1818 H St, NW, MSN MC3-303, Washington DC, 20433. Tel. (202) 458-8485. Email: bsmarzynska@worldbank.org. I wish to thank Enrique Aldaz-Carroll, Andrew Bernard, Simon Evenett, Ana Fernandes, Michael Ferrantino, Holger Görg, Mary Hallward-Driemeier, Pravin Krishna, Hiau Looi Kee, Maryla Maliszewska, Jacques Morisset, Marcelo Olarreaga, Maurice Schiff, Matt Slaughter, Mariana Spatareanu and the participants of the Tuck International Trade Summer Camp and the seminar at the Inter-American Development Bank for valuable comments and suggestions. The financial support received from the Foreign Investment Advisory Service (FIAS) - a joint facility of the IFC and the World Bank - is gratefully acknowledged. This paper is part of a larger FIAS effort to improve the understanding of spillovers from multinational corporations to local firms. The views expressed in the paper are those of the author and should not be attributed to the World Bank or its Executive Directors.
} 


\section{Introduction}

Following the advice of multilateral development agencies, policymakers in many developing and transition economies place attracting foreign direct investment (FDI) high on their agenda, expecting FDI inflows to bring new technologies, know-how and thus contribute to increasing productivity and competitiveness of domestic industries. Many countries go beyond national treatment of multinationals by offering foreign companies, through subsidies and tax holidays, more favorable conditions than those granted to domestic firms. ${ }^{1}$ As the economic rationale for this special treatment, policy makers cite positive externalities generated by FDI through productivity spillovers to domestic firms.

The only trouble is that there is no proof that positive productivity externalities generated by foreign presence actually exist. As Dani Rodrik (1999) remarked, "today's policy literature is filled with extravagant claims about positive spillovers from FDI but the evidence is sobering." Indeed the difficulties associated with disentangling different effects at play and data limitations have prevented researchers from providing conclusive evidence of positive externalities resulting from FDI. While recent firm-level studies have overcome many of the difficulties faced by the earlier literature, the emerging message is not very optimistic.

The existing literature on this subject is of three kinds. First, there are case studies including descriptions pertaining to particular FDI projects or specific countries, which however rarely offer quantitative information and are not easily generalized (see for instance, Rhee and Belot, 1989; Moran 2001). Then, there is a plethora of industry level studies, most of which show a positive correlation between foreign presence and sectoral productivity. ${ }^{2}$ Their downside is the difficulty in establishing the direction of causality. It is possible that this positive association is caused by the fact that multinationals tend to locate in high productivity industries rather than by genuine productivity spillovers. It may also be a result of FDI inflows forcing less productive domestic firms to exit and/or multinationals increasing their share of host country

\footnotetext{
${ }^{1}$ For instance, in the late 1980s, the state of Kentucky offered Toyota an incentive package worth (in present value) 125-147 million dollars for a plant expected to employ 3,000 workers. In 1991, Motorola was paid 50.75 million pounds to locate a mobile-phone factory employing 3,000 people in Scotland (Haskel et al., 2001, p. 1). FDI incentives are also offered by developing and transition economies. As an illustration, foreign firms in Hungary received 92.6 percent of all tax concessions provided in the country in 2000 (Csaki, 2001, p. 16).

${ }^{2}$ See, for example, the pioneering work by Caves (1974) focusing on Australia, Blomström and Persson's (1983) and Blomström and Wolff's (1994) papers on Mexico and the summary of studies on Mexican data by Blomström (1989).
} 
market, both of which would raise the average productivity in the industry. Finally, there is research based on firm-level panel data, which examines whether the productivity of domestic firms is correlated with the extent of foreign presence in their sector or region. However, most of these studies, such as for instance, careful analyses done by Haddad and Harrison (1993) on Morocco, Aitken and Harrison (1999) on Venezuela and Djankov and Hoekman (2000) on the Czech Republic cast doubt on the existence of spillovers from FDI in developing countries. The researchers either fail to find a significant effect or produce the evidence of negative horizontal spillovers, i.e., the effect the presence of multinational corporations has on domestic firms in the same sector. The picture is more optimistic in the case of industrialized countries as a recent paper by Haskel, Pereira and Slaughter (2002) provides convincing evidence of positive FDI spillovers in the UK. ${ }^{3}$

It is possible, though, that researchers have been looking for FDI spillovers in the wrong place. Since multinationals have an incentive to prevent information leakages that would enhance the performance of their local competitors, but at the same time may want to transfer knowledge to their local suppliers, spillovers from FDI are more likely to be vertical rather than horizontal in nature. In other words, spillovers are most likely to take place through backward linkages, that is contacts between domestic suppliers of intermediate inputs and their multinational clients, and thus they would not have been captured by the earlier studies. ${ }^{4}$

As Blomström et al. (2000) point out, however, there are hardly any empirical studies analyzing explicitly the relationship between linkages and spillovers. The notable exceptions are two recent papers by Blalock (2001) and Schoors and van der Tol (2001), which provide evidence of positive FDI spillovers through backward linkages. ${ }^{5}$ Moreover, despite the keen interest of policy makers in the subject, little is known about the factors driving vertical spillovers. This study takes the first step towards filling this gap in the literature.

The purpose of this study is twofold. First, it examines whether the productivity of domestic firms is correlated with the presence of multinationals in downstream sectors (i.e., their potential customers). Detecting such an effect would be consistent with the existence of broadly

\footnotetext{
${ }^{3}$ For a survey of the literature on horizontal spillovers from FDI see Görg and Strobl (2001).

${ }^{4}$ For a theoretical justification of spillovers through backward linkages see Rodriguez-Clare (1996), Markusen and Venables (1999) and Saggi (2002). For case studies see Moran (2001).

${ }^{5}$ Kugler (2000) also finds inter-sectoral technology spillovers from FDI in Colombia. However, he does not distinguish between different channels through which such spillovers may be occurring (e.g., backward versus forward linkages).
} 
defined spillovers through backward linkages. This paper improves over the existing literature by taking into account econometric problems that may have biased the results of earlier work. Namely, it employs the semiparametric estimation method suggested by Olley and Pakes (1996) to account for endogeneity of input demand. Moreover, standard errors are corrected to take into account the fact that the measures of potential spillovers are industry specific while the observations in the data set are at the firm level. As Moulton (1990) pointed out, failing to make such a correction will lead to serious downward bias in the estimated errors thus resulting in spurious finding of statistical significance for the aggregate variable of interest.

Second, this study goes beyond the existing literature by shedding some light on determinants of spillovers. It examines whether potential benefits stemming from vertical linkages are related to export-orientation of multinationals in downstream sectors and the extent of foreign ownership in affiliates. Based on case studies and investor surveys, these factors have often been conjectured to influence the extent and benefits of backward linkages, but to the best of our knowledge, their impact has not been systematically examined. ${ }^{6}$

The analysis is based on data from the annual enterprise survey conducted by the Lithuanian Statistical Office. The survey coverage is extensive, as firms accounting for about 85 percent of output in each sector are included. The data constitute an unbalanced panel covering the period 1996-2000. Focusing on a transition economy, such as Lithuania, seems very suitable for this project as the endowment of skilled labor enjoyed by transition countries makes them a particularly likely place where productivity spillovers could manifest themselves. ${ }^{7}$

The results can be summarized as follows. The empirical results are consistent with the existence of positive spillovers from FDI taking place through backward linkages but no indication of spillovers occurring through horizontal channels. In other words, firm productivity is positively correlated with the extent of potential contacts with multinational customers but not with the presence of multinationals in the same industry. The data also indicate that local firms benefit from the operation of foreign affiliates both in their own region and in other parts of the country, albeit the evidence of the latter outcome is weaker. The magnitude of the effect is economically meaningful. A one-standard-deviation increase in the foreign presence in the

\footnotetext{
${ }^{6}$ See UNCTC (2001, chapter 4) for a comprehensive review of this topic.

${ }^{7}$ For instance, during 1990-2000 the number of scientists and engineers in R\&D activities per million people was equal to 2,031 in Lithuania, as compared to 2,139 in Korea, 711 in Argentina, 168 in Brazil and 154 in Malaysia (Global Economic Indicators, 2002, World Bank).
} 
sourcing sectors (i.e., an increase in the backward variable of three percentage points) is associated with a ten percent rise in output of each firm in the supplying industry. As for the determinants, the productivity effect is found to be larger when the multinationals in the sourcing sector are oriented towards supplying the domestic market rather than focusing mainly on exporting. Finally, there is no statistically significant difference between the productivity effects associated with partially- and fully-owned foreign projects.

In summary, this paper adds to the understanding of externalities generated by FDI in a host country economy, which is a highly important issue for public policy. The finding of a positive correlation between firm productivity and multinational presence in downstream sectors is, however, by no means a call for subsidizing FDI. These results are consistent with the existence of knowledge spillovers from foreign affiliates to their local suppliers but they may also be due to increased competition in upstream sectors. The latter may be the case if multinationals entering downstream sectors force less productive domestic producers to exit thus lowering the demand for domestically produced intermediates, either because they are more efficient and need fewer inputs ${ }^{8}$ or they choose to import their inputs (due to their higher quality, constraints imposed by the parent company, etc.). The welfare implications of the two scenarios are quite different. While the former case would call for FDI incentives, it would not be the optimal policy in the latter. More research is certainly needed to disentangle these effects.

This study is structured as follows. The next section briefly discusses vertical spillovers and their determinants. It is followed by a description of FDI inflows into Lithuania. Then the data and the estimation strategy are presented. The following section presents the empirical results, and the closing section concludes.

\section{Vertical Spillovers and Their Determinants}

Productivity spillovers from FDI take place when the entry or presence of multinational corporations increases productivity of domestic firms in a host country and the multinationals do not fully internalize the value of these benefits. Spillovers may take place when local firms

\footnotetext{
${ }^{8}$ See Saggi’s (2002) model for such a scenario.
} 
improve their efficiency by copying technologies of foreign affiliates operating in the local market either based on observation or by hiring workers trained by the affiliates. Another kind of spillovers occurs if multinational entry leads to more severe competition in the host country market and forces local firms to use their existing resources more efficiently or to search for new technologies (Blomström and Kokko, 1998). While the knowledge spillovers present a rationale for governments to subsidize FDI inflows, this is not the case when the improved productivity of local firms is due to increased competition, as inducing greater competition may be achieved by other means (import liberalization, anti-trust policies, etc.).

When local firms benefit from the presence of foreign companies in their sector, this phenomenon is referred to as horizontal spillovers. To the extent that domestic firms compete with multinationals, the latter have an incentive to prevent technology leakage and spillovers from taking place. This can be achieved through formal protection of their intellectual property, trade secrecy, paying higher wages or locating in countries or industries where domestic firms have limited imitative capacities to begin with.

On the other hand, the term vertical spillovers (in this paper restricted to the backward linkage channel) refers to productivity spillovers taking place due to linkages between foreign firms and their local suppliers. Such spillovers can operate through: (i) direct knowledge transfer from foreign customers to local suppliers; ${ }^{9}$ (ii) higher requirements regarding product quality and on-time delivery introduced by multinationals, which provide incentives to domestic suppliers to upgrade their production management or technology; (iii) indirect knowledge transfer through labor turnover; (iv) increased demand for intermediate products due to multinational entry, which allows local suppliers to reap the benefits of scale economies; ${ }^{10}$ (v) competition effect-multinationals acquiring domestic firms may choose to source intermediates abroad thus breaking existing supplier-customer relationships and increasing competition in the intermediate products market. ${ }^{11}$

\footnotetext{
${ }^{9}$ As numerous case studies indicate (see Moran 2001), multinationals often provide technical assistance to their suppliers in order to raise the quality of their products or facilitate innovation. They help suppliers with management training and organization of the production process, purchasing raw materials and even finding additional customers. Note that the existence of linkages does not necessarily guarantee that spillovers take place nor does the fact that multinationals may charge for services provided preclude the presence of spillovers. Spillovers take place when foreign affiliates are unable to extract the full value of the resulting productivity increase through direct payment or lower prices they pay for intermediates sourced from the local firm.

${ }^{10}$ For a theoretical model, see Rivera-Batiz and Rivera-Batiz (1990).

${ }^{11}$ One of the largest FDI projects in Romania, Renault's purchase of an equity stake in Dacia, the local automobile maker, may serve as an example. The initial transaction took place in 1999 with subsequent increases in Renault's
} 
Consider factors that could potentially drive vertical spillovers. First, the motivation for undertaking FDI is likely to affect the extent of local sourcing by foreign affiliates. It has been suggested that domestic-market-oriented foreign affiliates tend to purchase more locally that export-oriented ones (UNCTAD 2000; Altenburg 2000; Belderbos et al. 2001). Quality and technical requirements associated with goods targeted for the domestic market may be lower and thus local suppliers may find it easier to serve multinationals focused on the domestic market. On the other hand, multinationals serving global markets may impose more stringent cost and quality requirements, which may be difficult for local suppliers to meet. Moreover, affiliates which are part of international production systems are likely to be more dependent on global sourcing policies of their parent company and thus have less freedom to choose their own suppliers.

Second, it has been argued that affiliates established through M\&As or joint ventures are likely to source more locally than those taking form of greenfield projects (UNCTC 2001). While the latter have to take time and effort to develop local linkages, the former can take advantages of the supplier relationships established by the acquired firm or their local partner. Empirical evidence to support this view has been found for Japanese investors (Belderbos et al., 2001) and for Swedish affiliates in Eastern and Central Europe (UNCTC 2000). ${ }^{12}$ While in the dataset used here it is impossible to distinguish between acquisitions, joint ventures and greenfield projects, it contains information on the extent of foreign ownership. To the extent that full foreign ownership is a proxy for greenfield projects, it is expected that fully-owned foreign affiliates will tend to rely more on imported inputs, while investment projects with local capital participation will tend to source more locally. Therefore, backward linkages associated with the latter group are likely to result in greater spillovers.

In what follows, the above hypotheses are examined. First, however, FDI-related developments in Lithuania are briefly reviewed.

share in 2001 and 2002. After the acquisition, the French company promised to continue sourcing inputs from local suppliers provided they lived up to the expectations of the new owner. This, however, does not seem to have been the case. In 2002, eleven foreign suppliers of the French group will start operating in Romania, thus replacing the Romanian producers from whom Dacia used to source. Source: Ziarul Financiar (Financial Newspaper) April 19, 2001.

${ }^{12}$ The results of a study of the largest exporters in Hungary (Toth and Semjen 1999) also indicate that foreign affiliates with larger shares of foreign equity tend to purchase fewer inputs from Hungarian companies. 


\section{Foreign Direct Investment in Lithuania}

Similarly to other former Soviet Republics, Lithuania had been virtually closed to foreign investment before 1990. After regaining its independence in 1990, Lithuania began the process of transition to a market economy and opened its borders to FDI. Yet unlike transition economies of Central and Eastern Europe (CEECs hereafter), it did not receive large FDI inflows until the late 1990s. The first stage of the privatization process, starting in 1991, offered limited opportunities for foreign investors. It was not until 1997 that FDI inflows into Lithuania increased significantly as a result of the second stage of the privatization process (see the chart below). As is evident from Table A below, the overall magnitude of FDI inflows has not been very large. In terms of cumulative FDI inflows per capita during the period 1993-2000, Lithuania ranks eighth among CEECs above Bulgaria and Romania. In terms of the value of cumulative FDI inflows, Lithuania ranks ninth exceeding only FDI receipts of Slovenia.

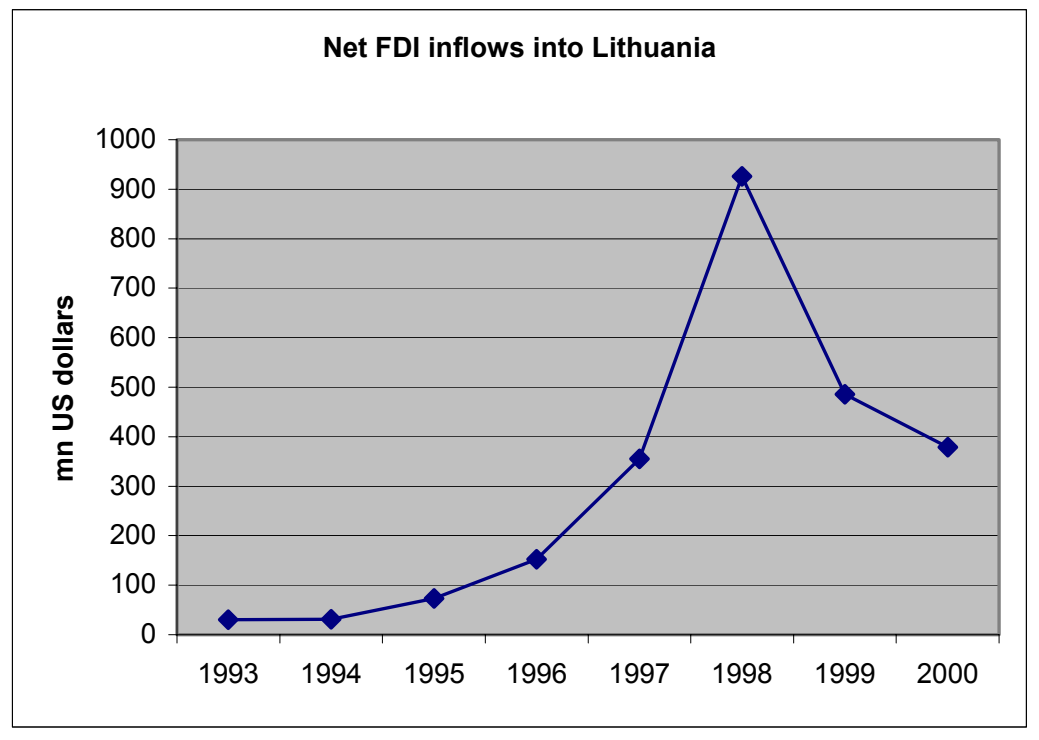


Table A. FDI Inflows into CEECs 1993-2000.

\begin{tabular}{|c|c|c|c|c|c|c|c|c|c|c|c|c|}
\hline & \multicolumn{8}{|c|}{ Net FDI inflow (millions of US\$) } & \multicolumn{2}{|c|}{$\begin{array}{c}\text { FDI inflows } \\
2000\end{array}$} & \multicolumn{2}{|c|}{$\begin{array}{c}\text { FDI inflows } \\
1993-2000\end{array}$} \\
\hline & 1993 & 1994 & 1995 & 1996 & 1997 & 1998 & 1999 & 2000 & $\begin{array}{c}\text { as } \% \text { of } \\
\text { GDP }\end{array}$ & $\begin{array}{c}\text { per } \\
\text { capita }\end{array}$ & $\begin{array}{c}\text { Value } \\
\text { (mn US\$) }\end{array}$ & $\begin{array}{c}\text { Per capita } \\
\text { (US\$) }\end{array}$ \\
\hline Czech Republic & 654 & 878 & 2,568 & 1,435 & 1,286 & 3,700 & 6,313 & 4,583 & 9.3 & 446 & 21,417 & 2,085 \\
\hline Hungary & 2,350 & 1,144 & 4,519 & 2,274 & 2,167 & 2,037 & 1,977 & 1,692 & 3.7 & 169 & 18,159 & 1,812 \\
\hline Estonia & 162 & 214 & 201 & 150 & 266 & 581 & 305 & 387 & 7.8 & 270 & 2,268 & 1,580 \\
\hline Poland & 1,715 & 1,875 & 3,659 & 4,498 & 4,908 & 6,365 & 7,270 & 9,342 & 5.9 & 242 & 39,632 & 1,025 \\
\hline Latvia & 45 & 214 & 180 & 382 & 521 & 357 & 348 & 407 & 5.7 & 169 & 2,454 & 1,015 \\
\hline Slovenia & 113 & 128 & 177 & 194 & 375 & 248 & 181 & 181 & 1.0 & 91 & 1,597 & 803 \\
\hline Slovak Republic & 199 & 270 & 236 & 351 & 174 & 562 & 354 & 2,052 & 10.7 & 380 & 4,198 & 777 \\
\hline Lithuania & 30 & 31 & 73 & 152 & 355 & 926 & 486 & 379 & 3.4 & 102 & 2,432 & 658 \\
\hline Bulgaria & 40 & 105 & 90 & 109 & 505 & 537 & 806 & 1,002 & 8.3 & 123 & 3,194 & 391 \\
\hline Romania & 94 & 341 & 419 & 263 & 1,215 & 2,031 & 1,041 & 1,025 & 2.8 & 46 & 6,429 & 287 \\
\hline
\end{tabular}

Source: IMF International Financial Statistics (FDI figures) and World Bank World Development Indicators (GDP and population)

In terms of sectoral distribution of FDI, 44 percent of the FDI stock in 1996 was in manufacturing. Following large inflows into the telecommunications and financial sectors, this figure decreased to 32 percent in 2000. When the number of projects is considered, in 199620 percent of FDI was in manufacturing, as compared to 21 percent in 2000. Within manufacturing, food products, beverages and tobacco attracted the largest share of investment (12 percent of total FDI stock), followed by textiles and leather products (4 percent) and refined petroleum and chemicals (4 percent). Electrical machinery, optical instruments and wood products also received significant foreign investments. As for service sectors, wholesale and retail trade accounted for a quarter of FDI stock in 2000, telecommunications for 18 percent and financial intermediation for 14 percent.

\section{Data and Methodology}

The data used in this study come from the annual enterprise survey conducted by the Lithuanian Statistical Office. The survey coverage is extensive, as firms accounting for about 85 percent of output in each sector are included in the sample. The Lithuanian enterprise data have been praised for their high quality and reliability. ${ }^{13}$ The data constitute an unbalanced panel covering the period 1996-2000. The number of firms per year varies from over twelve thousand in 1996 to twenty one thousand in 1999. Due to financial constraints in some years the

\footnotetext{
${ }^{13}$ A recent survey examining the quality of data collected by statistical offices ranked Lithuania second among twenty transition economies (see Belkindas et al., 1999).
} 
Statistical Office was forced to reduce the scope of the exercise. In each year, however, the same sampling technique was used. In this study, the attention is restricted to manufacturing firms only (NACE sectors 15-36), which lowers the sample size to 2,500 to 4,000 firms a year. The number of observations is further reduced by missing values. Moreover, two sectors tobacco (NACE 16) and manufacturing of refined petroleum products (NACE 23) are excluded, since the small number of firms makes it impossible to apply the Olley-Pakes technique (discussed below) to these industries. Thus the final sample size varies between 1,921 and 2,712 firms in a given year. The sectoral distribution of firms in the last year of the sample is presented in Table 1.

In addition to standard financial statements, the dataset contains information on the amount of foreign capital, if any, that has been invested in each firm, which allows for making comparisons between FDI recipients and locally owned firms. FDI recipients are defined as firms with the foreign share equal to at least ten percent of total capital. More than 12 percent of the total of 11,644 observations pertain to such firms. The dataset also includes information on the share of exports in firm sales.

To examine the correlation between firm productivity and foreign presence in the same industry or downstream sectors, the approach taken by the earlier literature is followed and several variations of the following equation are estimated:

$$
\begin{gathered}
\ln Y_{i j r t}=\alpha+\beta_{1} \ln K_{i j r t}+\beta_{2} \ln L_{i j r t}+\beta_{3} \ln M_{i j r t}+\beta_{4} F S_{i j r t}+\beta_{5} \text { Horizontal }_{j t}+\beta_{6} \text { Backward }_{j t}+\alpha_{t} \\
+\alpha_{r}+\alpha_{j}+\varepsilon_{i j r t}
\end{gathered}
$$

$Y_{i j r t}$ stands for the real output of firm $\mathrm{i}$ operating in sector $\mathrm{j}$ and region $\mathrm{r}$ at time $\mathrm{t}$, which is calculated by adjusting the reported sales for changes in inventories of finished goods and deflating the resulting value by the Producer Price Index for the appropriate two-digit NACE sector. $K_{i j r}$, capital, is defined as the value of fixed assets at the beginning of the year, deflated by the average of the deflators for four NACE sectors: machinery and equipment; office, accounting and computing machinery; electrical machinery and apparatus; motor vehicles, trailer and semi-trailers; and other transport equipment. $L_{i j r}$, employment, is measured by the number of workers. ${ }^{14} M_{i j r}$, material inputs, are equal to the value of material inputs adjusted for changes in material inventories, deflated by material inputs deflator calculated for each sector based on

\footnotetext{
${ }^{14}$ Ideally we would like to have information on hours worked but, unfortunately, it is not available. Neither can we distinguish between skilled and unskilled workers.
} 
the two-digit input-output matrix and deflators for the relevant two-digit NACE sectors. $F S_{i j r t}$ measures the share of foreign capital in firm's total capital.

Horizontal $_{j t}$ captures the extent of foreign presence in sector $\mathrm{j}$ at time $\mathrm{t}$ and is defined as foreign equity participation averaged over all firms in the sector, weighted by each firm's share in sectoral output. ${ }^{15}$ In other words,

$$
\text { Horizontal }_{j t}=\left[\Sigma_{\text {ifor all } i \in j} F S_{i j t} * Y_{i j t}\right] / \Sigma_{\text {ifor all } i \in j} Y_{i j t}
$$

Thus the value of the variable increases with the output of foreign investment enterprises and the share of foreign capital in these firms.

The variable Backward is a proxy for the foreign presence in the industries that are being supplied by the sector to which the firm in question belongs and thus is intended to capture the extent of potential contacts between domestic suppliers and multinational customers. ${ }^{16}$ It is defined in the following way:

$$
\text { Backward }_{j t}=\Sigma_{k \text { if } k \neq j} \alpha_{j k} \text { Horizontal }_{k t}
$$

where $\alpha_{j k}$ is the proportion of sector j's output supplied to sector k taken from the 1996 inputoutput matrix at the two-digit NACE level. The proportion is calculated excluding products supplied for final consumption but including imports of intermediate products. ${ }^{17}$ As the formula indicates, inputs supplied within the sector are not included, since this effect is already captured by the Horizontal variable. ${ }^{18}$ Thus the greater the foreign presence in sectors supplied by industry $\mathrm{j}$ and the larger the share of intermediates supplied to industries with multinational presence, the higher the value of the variable.

While the coefficients taken from the input-output table remain fixed, changes in foreign presence and firm output are observed during the period in question. Thus the variables

\footnotetext{
${ }^{15}$ This definition is analogous to that in Aitken et al. (1999) who use employment as weights. Blalock (2001) and Schoors et al. (2001) employ output weights but do not take into account the share of foreign equity, treating total output of firms with at least ten percent foreign equity as foreign.

${ }^{16}$ To illustrate the meaning of the variable, suppose that the sugar industry sells half of its output to jam producers and half to chocolate producers. If there are no multinationals producing jam but half of all chocolate production comes from foreign affiliates, the Backward variable will be calculated as follows $1 / 2 * 0+1 / 2 * 1 / 2=0.25$.

${ }^{17}$ Since relationships between sectors may change over time (although a radical change is unlikely), ideally we would like to use multiple input-output matrices. Unfortunately, input-output matrices for later years are unavailable. Similarly, while we would prefer to use a matrix excluding imports, it is not available. Thus, our results should be interpreted keeping these two caveats in mind.

${ }^{18}$ This approach is followed by Schoors et al. (2001) but not by Blalock (2001). Including the share of intermediates supplied within the sector in the Backward measure (as was done in an earlier version of this paper) does not change the conclusions with respect to the correlation between firm productivity and foreign presence in the sourcing sectors.
} 
capturing horizontal and vertical linkages are time-varying sector-specific variables. Table 1 lists the values of both variables in year 2000. In addition to the calculation described above, the Horizontal variable is recalculated making it firm specific by excluding the output of the firm in question in the calculations. Since both definitions lead to the same qualitative results, only the results with the latter measure are presented. ${ }^{19}$ Finally, the basic specification of the model also includes year, region and industry dummies. Summary statistics for the variables employed are presented in Table 2.

Several econometric concerns need to be addressed. The first concern is the omission of unobserved variables. There may exist firm, time and region specific factors unknown to econometrician but known to the firm that may affect the correlation between firm productivity and foreign presence. Examples of these variables include high quality management in a particular firm or better infrastructure present in a given region. This problem is addressed by following Haskel et al. (2002) and using time differencing as well as a full set of fixed effects for year, industry and region. As Haskel et al. point out, in addition to removing any fixed plantspecific unobservable variation, differencing will also remove fixed regional and industrial effects such as infrastructure and technological opportunity. Time, industry and regional dummy variables on the other hand will control for unobservables that may be driving changes in, for instance, attractiveness of a particular region or industry. ${ }^{20}$ Thus the specification becomes

$$
\begin{gathered}
\Delta \ln Y_{i j r t}=\alpha+\delta_{1} \Delta \ln K_{i j r t}+\Delta \delta_{2} \Delta \ln L_{i j r t}+\delta_{3} \Delta \ln M_{i j r t}+\delta_{4} \Delta F S_{i j r t}+\delta_{5} \Delta \text { Horizontal }_{j t} \\
+\delta_{6} \Delta \text { Backward }_{j t}+\alpha_{t}+\alpha_{r}+\alpha_{j}+\varepsilon_{i j r t}
\end{gathered}
$$

Second, as Djankov and Hoekman (2000) and Evenett and Voicu (2001) have shown, foreign investors tend to acquire stakes in the largest and most successful companies in transition economies. If this issue is not taken into account, the estimation results could be biased. To avoid such a bias, the model is also estimated on a sample of domestic firms only. ${ }^{21}$ Additionally, the two-step procedure devised by Maddala (1983) has been used. The procedure amounts to estimating first a probit model on whether or not firm i ever received FDI on firm size (measured by total capital) and profitability (measured by the ratio of gross profits to sales)

\footnotetext{
${ }^{19}$ Note that recalculating the Horizontal variable will not affect the Backward measure since it does not take into account inputs suppliers to own sector.

${ }^{20}$ As Haskel et al. mention, in this case a fixed effect for region $r$ captures not just the fact that region $r$ is an attractive business location but that its attractiveness is rising over time.

${ }^{21}$ Domestic firms are defined as those with less than ten percent of foreign equity.
} 
in the first year of the sample, subsequently not used in the second stage. The estimates from the first stage are then used to form an additional regressor in the second stage estimation of productivity on foreign presence, annual and regional dummies. The results (not reported here) led to the same qualitative results.

Third, it has been argued that the use of ordinary least squares may be inappropriate when estimating productivity since this method treats labor and other inputs as exogenous variables. Griliches and Mairesse (1995) have argued that inputs should be considered endogenous since they are chosen by firm based on its productivity, which is observed by the producer but not by the econometrician. Not taking into account the endogeneity of input choices may bias the estimated coefficients. Since the focus of this paper is on firm productivity, the consistency of the estimates is crucial for the analysis. Therefore, the semiparametric estimation procedure suggested by Olley and Pakes (1996) is employed. ${ }^{22}$ The details of the procedure are described in the Appendix.

A production function, taking into account the Olley-Pakes correction, is separately estimated for each industry. From this estimation, the measure of total factor productivity, which is the difference between the actual and predicted output, is recovered and used in the estimation of the basic model. Note that the Olley-Pakes procedure rests on the assumption of factors fully adjusting to shocks in each period and markets being perfectly competitive. Since there may be some doubt about the validity of these assumptions, particularly in the context of a transition economy, the results both with and without the correction are presented. ${ }^{23}$ Further, while this method also allows for controlling for firm exit, this option is not utilized here since, unfortunately, the dataset does not allow for distinguishing between firm exit from the sample due to liquidation or due to not being included in the group of enterprises surveyed in a given year.

The last but not the least econometric concern has been pointed out by Moulton (1990) who shows that in the case of regressions performed on micro units yet including aggregated market (or in this case industry) variables the standard errors from ordinary least squares will be underestimated. As he demonstrates, failing to take this into account will lead to a serious

\footnotetext{
22 This method has been recently applied by, for instance, Pavcnik (2002).

${ }^{23}$ As stated in Olley-Pakek (1996), the correction should be applied only to firms with positive investment figures. Thus to make the results with and without correction directly comparable we employ the same sample of firms in both types of regressions. Note that regressions not involving the Olley-Pakes correction estimated on the full sample of firms (i.e., including firms with zero investments) lead to the same qualitative results.
} 
downward bias in the estimated errors resulting in spurious finding of statistical significance for the aggregate variable of interest. To address this issue, the standard errors are corrected for a correlation between observations belonging to the same industry in a given year (in other words, standard errors are clustered for all observations in the same industry and year).

To the best of our knowledge, none of the earlier spillover studies has taken into account all of the above concerns. As for the papers on vertical spillovers, Schoors et al. (2001) employ a two-step selection procedure but do not include firm or industry fixed effects (since their dataset pertains to a two-year period only), while Blalock (2001) controls for firm fixed effects but not for the selection issue. Neither study includes differencing of spillover variables, a correction for endogeneity of input choices or a correction of errors for the downward bias pointed out by Moulton (1990).

\section{Estimation Results}

The results from the first differences model described in the previous section are presented in Table 3. The first two columns contain the coefficients estimated for the full sample followed by those for the subsample of domestic firms. All of them pertain to the model without the Olley-Pakes correction. As expected, positive and significant coefficients on the changes in all production inputs as well as on the change in the share of foreign equity are obtained. The latter finding implies that an increase in foreign capital participation in a given firm is associated with faster output growth. As in earlier studies, the coefficient on the proxy for horizontal spillovers does not appear to be statistically significant. More importantly for this study, the regressions produce a positive and significant coefficient on the measure of backward linkages both in the full sample and the subsample of domestic firms. The magnitude of the effect is economically meaningful. A one-standard-deviation increase in the foreign presence in the sourcing sectors (i.e., an increase in the backward variable of three percentage points) is associated with a ten percent rise in output of each domestic firm in the supplying industry.

When the Olley-Pakes correction is applied (see the last four columns of Table 3), the coefficients on the backward variable are positive but not significant at the conventional levels. As before, a positive correlation between the change in the foreign equity share and firm productivity growth is found but there is no indication of the presence of horizontal spillovers. 
The next issue to be addressed is whether potential spillovers operate at the regional or national level. To examine this question the Backward measure is calculated for the region of the firm in question as well as separately for all other regions. Since Lithuania is a relatively small country, for the purpose of this exercise ten regions are considered. Analogously, one measure of horizontal spillovers is computed for the region where the firm in question is located and another measure for all other regions. Note that the measures pertaining to own region are firm specific since they exclude the output of the firm in question. Since in this model, there is no problem of mixing industry-specific variables with firm-specific observations, standard errors are corrected for heteroskedasticity but not clustered on each industry.

The results presented in Table 4 show a positive and significant correlation between firm productivity and foreign presence in downstream sectors in the same region. The coefficients are significant in all eight regressions, even when the Olley-Pakes correction is applied. The coefficients are larger in magnitude and more significant in the case of the domestic firm subsample. As for the impact of downstream multinationals in other regions, this effect is positive and significant only in the first four columns of the table. The proxies for foreign presence in the same sector (both in the same region and other parts of the country) do not appear to be statistically significant. In summary, there is strong evidence of positive correlation between firm output growth and the change in foreign presence in downstream sectors in the same region and less robust evidence with respect to foreign presence in other regions.

As mentioned before, case studies and evidence based on particular sectors suggest that domestic-market-oriented affiliates tend to source more locally than the affiliates focused on exporting. And since the extent of spillovers is likely to be correlated with the intensity of contacts between domestic firms and multinationals, one would expect to observe greater spillovers associated with domestic-market-oriented affiliates. To examine this question, two separate measures of backward linkages are calculated: one for affiliates exporting more than half of their output and one for foreign firms selling at least half of their output locally. The latter variable is defined as follows:

$$
\begin{gathered}
\text { Backward (Domestic-Market-Oriented })_{j t}=\Sigma_{k i f k \neq j} \alpha_{j k} *\left[\Sigma_{i \text { for all } i \in k} F S_{i k t} * D M O_{i k t} * \text { Output }_{i k t}\right] / \\
\sum_{i \text { for all } i \in k} \text { Output } t_{i k t}
\end{gathered}
$$


where $\mathrm{DMO}_{\mathrm{ikt}}=1$ if firm i sold at least half of its output in the local market. Otherwise, it takes on a value of zero. The measure for export-oriented affiliates in calculated analogously. Both measures are included in the model keeping the horizontal variable defined as before.

The results presented in Table 5 provide some support for the hypothesis. While in all eight regressions both backward measures are positive and statistically significant, their coefficients are larger in the case of domestic-market-oriented affiliates. The difference in magnitude between the two types of backward measures is statistically significant at the one percent level in four cases, five percent in two cases and ten percent in the remaining two regressions. Thus the results suggest that greater FDI spillovers are associated with the presence of multinationals producing for the domestic market rather than those using Lithuania as an export platform.

Next consider the hypothesis that backward linkages associated with partially-owned foreign projects lead to greater spillovers than linkages associated with wholly-owned foreign affiliates. To examine this question two measures of backward linkages are calculated: one for firms with the share of foreign capital equal to at least 99 percent and another one for enterprises with foreign participation above 10 but less than 99 percent. $^{24}$

The results shown in Table 6, however, lend little support to the hypothesis. While there is evidence of a significant positive correlation between firm's output growth and backward linkages associated with jointly-owned foreign affiliates but not those associated with whollyowned foreign projects, the difference between the magnitudes of the two coefficients is not statistically significant. Moreover, when the Olley-Pakes correction is applied, neither of the backward variables is statistically significant. Thus, the extent of foreign ownership does not appear to have an effect on the benefits stemming from foreign presence in downstream sectors.

\footnotetext{
${ }^{24}$ There are 262 observations pertaining to fully owned foreign affiliates and further 25 observations for firms with foreign capital share of more than 99 and less than 100 percent.
} 


\section{Conclusions}

Many countries, including developing and transition economies, compete against one another in attracting foreign investors by offering ever more generous incentive packages and justifying their actions with the productivity gains that are expected to accrue to domestic producers from knowledge externalities generated by foreign affiliates. Despite this question being hugely important to public policy choices, there is little conclusive evidence to support this claim.

This study is an effort to further the understanding of this issue. It examines whether there exists a correlation between productivity growth of domestic firms and the presence of foreign affiliates in downstream sectors. It improves over the existing literature by focusing on the understudied issue of FDI spillovers through backward linkages (i.e., contacts between foreign affiliates and their local suppliers) rather than the horizontal channel (i.e., benefits enjoyed by domestic firms from foreign presence in their sector) and going beyond the existing studies by shedding some light on factors driving this phenomenon. This study also addresses several econometric problems that may have biased the results of the earlier research.

The estimation results, based on a firm-level panel data set from Lithuania, are consistent with the presence of productivity spillovers taking place through backward linkages. They suggest that a three-percentage-point increase in the foreign presence in downstream sectors is associated with a ten-percent rise in firm output. Moreover, the data indicate that local firms benefit from the operation of foreign affiliates in downstream sectors in their own region as well as in other parts of the country, with the evidence of the latter effect being weaker, however. Further, greater productivity benefits are found to be associated with domestic-market- rather than export-oriented foreign companies. No difference is detected, though, between the effects of fully-owned foreign firms and those with joint domestic and foreign ownership.

As is often the case with empirical studies, the results are subjects to several caveats. The definitions of industries are quite broad and thus inevitably producers of products that are significantly different may be lumped together. Moreover, given the data limitation, it is not possible to control for firm entry and exit. Finally, it is important to emphasize that the findings of a positive correlation between productivity growth enjoyed by domestic firms and the increase in multinational presence in downstream sectors should not be interpreted as a call for 
subsidizing FDI. These results are consistent with the existence of knowledge spillovers from foreign affiliates to their local suppliers but they may also be due to increased competition in upstream sectors. While the former case would call for offering FDI incentive packages, it would not be the optimal policy in the latter. Further research is certainly needed to disentangle different channels through which FDI spillovers operate. 


\section{Bibliography}

Aitken, Brian J. and Ann E. Harrison. 1999. "Do Domestic Firms Benefit from Direct Foreign Investment? Evidence from Venezuela,” American Economic Review. 89(3): 605-618

Altenburg, Tilman. 2000. "Linkages and Spillovers between Transnational Corporations and Small and Medium-sized Enterprises in Developing Countries: Opportunities and Best Policies," in UNCTAD, TNC-SME Linkages for Development: Issues-Experiences-Best Practices. New York and Geneva: United Nations.

Belderbos, Rene, Giovanni Capannelli and Kyoji Fukao. 2001. "Backward vertical linkages of foreign manufacturing affiliates: Evidence from Japanese multinationals," World Development, 29(1): 189-208.

Belkindas, Misha, Mustafa Dinc, and Olga Ivanova. 1999. "Statistical Systems Need Overhaul in Transition Economies", Transition, 10(4), The World Bank, Washington, DC.

Blalock, Garrick. 2001. "Technology from Foreign Direct Investment: Strategic Transfer through Supply Chains," mimeo, Haas School of Business, University of California, Berkeley.

Blomström, Magnus. 1989. Foreign investment and spillovers. London: Routledge.

Blomström, Magnus and Ari Kokko. 1998. "Multinational Corporations and Spillovers,” Journal of Economic Surveys, 12(2): 1-31.

Blomström, Magnus, Ari Kokko and Mario Zejan. 2000. Foreign Direct Investment: Firm and Host Country Strategies. Macmillan Press: London.

Blomström, Magnus and Hakan Persson. 1983. "Foreign Investment and Spillover Efficiency in an Underdeveloped Economy: Evidence from the Mexican Manufacturing Industry," World Development, 11(6): 493-501.

Blomström, Magnus and Edward W. Wolff. 1994. "Multinational Corporations and Productivity Convergence in Mexico," in W. Baumol, R. Nelson and E. Wolff (eds.) Convergence of Productivity: Cross-national Studies and Historical Evidence. Oxford: Oxford University Press.

Caves, Richard E. 1974. "Multinational Firms, Competition and Productivity in Host-Country Markets," Economica, 41(162): 176-93.

Csaki, Gyorgy. 2001. "From Transition to Integration: FDI Inflows into Hungary, a Success Story of the Hungarian Transition," mimeo, Budapest College of Management.

Djankov, Simeon and Bernard Hoekman. 2000. "Foreign Investment and Productivity Growth in Czech Enterprises," World Bank Economic Review, 14(1): 49-64.

Evenett, Simon. J. and Alexandru Voicu. 2001. "Picking Winners or Creating Them? Revisiting the Benefits of FDI in the Czech Republic?" mimeo, the World Bank.

Görg, Holger and Eric Strobl. 2001. "Multinational Companies and Productivity Spillovers: A Meta-Analysis." The Economic Journal, 111: 723-39.

Griliches, Z. and J. Mairesse. 1995. "Production Functions: the Search for Identification,” NBER Working Paper 5067. 
Haddad, Mona and Ann Harrison. 1993. "Are there positive spillovers from direct foreign investment? Evidence from panel data for Morocco," Journal of Development Economics, 42: 51-74.

Haskel, Jonathan E., Sonia C. Pereira and Matthew J. Slaughter. 2002. "Does Inward Foreign Direct Investment Boost the Productivity of Domestic Firms?" NBER Working Paper 8724.

Kugler, Maurice. 2000. “The Diffusion of Externalities from Foreign Direct Investment: Theory Ahead of Measurement," Discussion Papers in Economics and Econometrics, University of Southampton, U.K.

Maddala, G.S. 1983. Limited-dependent and Qualitative Variables in Econometrics. Cambridge: Cambridge University Press.

Markusen, James R. and Anthony J. Venables. 1999. "Foreign direct investment as a catalyst for industrial development," European Economic Review. 43(1999): 335-356.

Moran, Theodore. 2001. Parental Supervision: the new paradigm for foreign direct investment and development. Institute for International Economics, Washington, DC.

Moulton, Brent R. "An Illustration of a Pitfall in Estimating the Effects of Aggregate Variables on Micro Units," Review of Economics and Statistics, 72(2): 334-338.

Olley, Steven G. and Ariel Pakes. 1996. "The Dynamics of Productivity in the Telecommunications Equipment Industry," Econometrica 64(6), pp. 1263-1297.

Pavcnik, Nina. 2002. "Trade Liberalization, Exit, and Productivity Improvements: Evidence from Chilean Plants," The Review of Economic Studies, 69: 245-76

Rhee, Jong Wong and Therese Belot. 1990. "Export Catalysts in Low-Income Countries: A Review of Eleven Success Stories," World Bank Discussion Paper No. 72, Washington, DC.

Rivera-Batiz, F. and L. Rivera-Batiz. 1990. "The effects of direct foreign investment in the presence of increasing returns due to specialization," Journal of Economic Development, 34(2): 287-307.

Rodrik, Dani. 1999. "The new global economy and developing countries: making openness work", Policy Essay nr. 24, Overseas Development Council; John Hopkins Univ. Press, Washington DC.

Rodriguez-Clare, Andres. 1996. "Multinationals, linkages, and economic development," American Economic Review 85, pp. 852-73.

Saggi, Kamal. 2002. "Backward Linkages under Foreign Direct Investment," mimeo, Southern Methodist University.

Schoors, Koen and Bartoldus van der Tol. 2001. "The productivity effect of foreign ownership on domestic firms in Hungary," mimeo, University of Gent.

Toth, Istvan Janos and Andras Semjen. 1999. "Market Links and Growth Capacity of Enterprises in A Transforming Economy: The Case of Hungary," in Istvan Janos Toth and Andras Semjen Market Links, Tax Environment and Financial Discipline of 
Hungarian Enterprises, Institute of Economics, Hungarian Academy of Sciences, Budapest.

UNCTAD. 2000. The Competitiveness Challenge: Transnational Corporations and Industrial Restructuring in Developing Countries. New York and Geneva: United Nations.

UNCTC. 2001. World Investment Report. Promoting Linkages. New York and Geneva: United Nations. 
Table 1. Distribution of Firms with Foreign Capital by Industry in 2000

\begin{tabular}{|c|c|c|c|c|c|c|c|}
\hline \multicolumn{2}{|c|}{ NACE } & $\begin{array}{c}\begin{array}{c}\text { Domestically } \\
\text { Owned } \\
\text { Firms } \\
\text { (1) }\end{array} \\
437\end{array}$ & $\begin{array}{c}\text { Firms with } \\
\text { Foreign } \\
\text { Capital* } \\
\text { (2) }\end{array}$ & $\begin{array}{c}\text { All Firms } \\
\text { (3) } \\
492\end{array}$ & $\begin{array}{c}(2) /(3) * 100 \\
11\end{array}$ & $\begin{array}{c}\text { Horizontal } \\
26.6\end{array}$ & $\begin{array}{c}\text { Backward } \\
1.5\end{array}$ \\
\hline 17 & Manuf. of textiles & 84 & 34 & 118 & 29 & 39.7 & 13.7 \\
\hline 20 & Manuf. of wood \& wood products except furniture & 432 & 47 & 479 & 10 & 34.3 & 12.5 \\
\hline 22 & Publishing, printing \& reproduction of recorded media & 225 & 12 & 237 & 5 & 7.0 & 3.5 \\
\hline 24 & Manuf. of chemicals \& chemical products & 48 & 17 & 65 & 26 & 21.0 & 7.4 \\
\hline 26 & Manuf. of other non-metallic mineral products & 148 & 18 & 166 & 11 & 35.3 & 3.1 \\
\hline 28 & Manuf. of fabricated metal products, exc. machinery & 169 & 25 & 194 & 13 & 10.7 & 8.4 \\
\hline 29 & Manuf. of machinery \& equipment n.e.c & 106 & 13 & 119 & 11 & 23.2 & 6.9 \\
\hline 31 & Manuf. of electrical mach. \& apparatus n.e.c. & 43 & 5 & 48 & 10 & 65.3 & 7.1 \\
\hline 32 & Manuf. of radio, tv, communication equipment & 28 & 5 & 33 & 15 & 32.2 & 14.4 \\
\hline 33 & Manuf. of medical, precision \& optical instruments & 46 & 9 & 55 & 16 & 23.8 & 11.9 \\
\hline
\end{tabular}

* foreign share of at least 10 percent of total capital 
William Davidson Institute Working Paper 548

Table 2. Summary Statistics

\begin{tabular}{lrrrrr}
\hline Variable & No. of obs. & Mean & Std. Dev. & Min & Max \\
\hline & & & & & \\
Output & 11,652 & $5,587,446$ & $24,300,000$ & 11 & $660,000,000$ \\
No. of employees & 11,652 & 84 & 238 & 1 & 6,176 \\
Fixed Assets & 11,652 & $2,587,088$ & $11,000,000$ & 10 & $298,000,000$ \\
Material Inputs & 11,652 & $2,898,996$ & $13,300,000$ & 2 & $376,000,000$ \\
Gross Investment & 11,652 & 429,823 & $2,681,202$ & 0 & $82,300,000$ \\
Foreign capital share (\%) & 11,644 & 7.8 & 23.0 & 0 & 100.0 \\
Exports/Output (\%) & 9,776 & 21.0 & 34.0 & 0 & 100.0 \\
Horizontal (\%) & 11,644 & 19.7 & 12.3 & 0 & 79.5 \\
Horizontal same region (\%) & 11,633 & 15.8 & 15.6 & 0 & 100.0 \\
Horizontal other region (\%) & 11,652 & 19.3 & 13.9 & 0 & 81.0 \\
Backward (\%) & 11,652 & 4.9 & 4.0 & 0 & 17.2 \\
Backward same region (\%) & 11,652 & 2.8 & 2.9 & 0 & 30.0 \\
Backward other region (\%) & 11,652 & 4.3 & 3.8 & 0 & 18.5 \\
Backward (Export-oriented MNCs) & 11,652 & 3.1 & 2.6 & 0 & 16.6 \\
Backward (Local-market-oriented MNCs) & 11,652 & 1.8 & 2.0 & 0 & 13.4 \\
Backward (Full ownership) & 11,652 & 1.9 & 2.0 & 0 & 14.7 \\
Backward (Shared ownership) & 11,652 & 3.0 & 2.5 & 0 & 8.9 \\
& & & & & \\
\hline
\end{tabular}


Table 3. Regresions in First Differences

\begin{tabular}{|c|c|c|c|c|c|c|c|c|}
\hline & & & & & \multicolumn{4}{|c|}{ with Olley-Pakes correction } \\
\hline & \multicolumn{2}{|c|}{ All firms } & \multicolumn{2}{|c|}{ Domestic firms } & \multicolumn{2}{|c|}{ All firms } & \multicolumn{2}{|c|}{ Domestic firms } \\
\hline$\Delta \ln \mathrm{L}$ & $\begin{array}{r}0.373 * * * \\
(0.019)\end{array}$ & $\begin{array}{r}0.373 * * * \\
(0.019)\end{array}$ & $\begin{array}{r}0.360 * * * \\
(0.021)\end{array}$ & $\begin{array}{r}0.359 * * * \\
(0.021)\end{array}$ & & & & \\
\hline$\Delta \ln \mathrm{K}$ & $\begin{array}{r}0.040 * * * \\
(0.013)\end{array}$ & $\begin{array}{r}0.040 * * * \\
(0.013)\end{array}$ & $\begin{array}{r}0.038 * * * \\
(0.012)\end{array}$ & $\begin{array}{r}0.039 * * * \\
(0.012)\end{array}$ & & & & \\
\hline$\Delta \ln \mathrm{M}$ & $\begin{array}{r}0.212 * * * \\
(0.020)\end{array}$ & $\begin{array}{r}0.212 * * * \\
(0.020)\end{array}$ & $\begin{array}{c}0.212 * * * \\
(0.019)\end{array}$ & $\begin{array}{r}0.212 * * * \\
(0.019)\end{array}$ & & & & \\
\hline$\Delta$ Foreign share & $\begin{array}{r}0.001 * * \\
(0.001)\end{array}$ & $\begin{array}{r}0.001 * * \\
(0.001)\end{array}$ & & & $\begin{array}{r}0.001 * * \\
(0.001)\end{array}$ & $\begin{array}{r}0.001 * * \\
(0.001)\end{array}$ & & \\
\hline$\Delta$ Backward & $\begin{array}{l}0.038 * \\
(0.019)\end{array}$ & $\begin{array}{l}0.038 * \\
(0.019)\end{array}$ & $\begin{array}{l}0.038 * \\
(0.021)\end{array}$ & $\begin{array}{l}0.038 * \\
(0.021)\end{array}$ & $\begin{array}{r}0.030 \\
(0.025)\end{array}$ & $\begin{array}{r}0.030 \\
(0.025)\end{array}$ & $\begin{array}{r}0.030 \\
(0.027)\end{array}$ & $\begin{array}{r}0.030 \\
(0.027)\end{array}$ \\
\hline$\Delta$ Horizontal & & $\begin{array}{l}-0.001 \\
(0.002)\end{array}$ & & $\begin{array}{r}0.000 \\
(0.002)\end{array}$ & & $\begin{array}{r}0.000 \\
(0.002)\end{array}$ & & $\begin{array}{r}0.000 \\
(0.003)\end{array}$ \\
\hline Intercept & $\begin{array}{r}-0.056 \\
(0.056)\end{array}$ & $\begin{array}{r}-0.054 \\
(0.057)\end{array}$ & $\begin{array}{r}-0.068 \\
(0.049)\end{array}$ & $\begin{array}{r}-0.070 \\
(0.050)\end{array}$ & $\begin{array}{r}-0.057 \\
(0.058)\end{array}$ & $\begin{array}{l}-0.055 \\
(0.057)\end{array}$ & $\begin{array}{l}-0.075 \\
(0.057)\end{array}$ & $\begin{array}{r}-0.078 \\
(0.057)\end{array}$ \\
\hline Year dummies & yes & yes & yes & yes & yes & yes & yes & yes \\
\hline Industry dummies & yes & yes & yes & yes & yes & yes & yes & yes \\
\hline Regional dummies & yes & yes & yes & yes & yes & yes & yes & yes \\
\hline No. of obs. & 6862 & 6862 & 5925 & 5923 & 6862 & 6862 & 5925 & 5923 \\
\hline F-stat & 51.96 & 50.56 & 42.4 & 42.38 & 2.86 & 2.77 & 2.15 & 2.13 \\
\hline Prob $>$ F & 0.00 & 0.00 & 0.00 & 0.00 & 0.00 & 0.00 & 0.00 & 0.00 \\
\hline $\mathrm{R}^{2}$ & 0.38 & 0.38 & 0.37 & 0.37 & 0.01 & 0.01 & 0.01 & 0.01 \\
\hline
\end{tabular}

Standard errors in parenthesis have been corrected for clustering for each industry in each year. $* * *, * *$, denote significance at 1,5 and $10 \%$ level. 
Table 4. Regresions in First Differences. Intra- versus Inter-regional Spillovers

\begin{tabular}{|c|c|c|c|c|c|c|c|c|}
\hline \multirow[b]{3}{*}{$\Delta \ln \mathrm{L}$} & & & & & \multicolumn{4}{|c|}{ with Olley-Pakes correction } \\
\hline & \multicolumn{2}{|c|}{ All firms } & \multicolumn{2}{|c|}{ Domestic firms } & \multicolumn{2}{|c|}{ All firms } & \multicolumn{2}{|c|}{ Domestic firms } \\
\hline & $\begin{array}{r}0.372 * * * \\
(0.018)\end{array}$ & $\begin{array}{r}0.372 * * * \\
(0.018)\end{array}$ & $\begin{array}{r}0.359 * * * * \\
(0.019)\end{array}$ & $\begin{array}{r}0.359 * * * * \\
(0.019)\end{array}$ & & & & \\
\hline$\Delta \ln \mathrm{K}$ & $\begin{array}{r}0.040 * * * \\
(0.010)\end{array}$ & $\begin{array}{r}0.040 * * * \\
(0.010)\end{array}$ & $\begin{array}{r}0.038 * * * * \\
(0.011)\end{array}$ & $\begin{array}{r}0.039 * * * * \\
(0.011)\end{array}$ & & & & \\
\hline$\Delta \ln \mathrm{M}$ & $\begin{array}{r}0.213 * * * \\
(0.011)\end{array}$ & $\begin{array}{r}0.212 * * * \\
(0.011)\end{array}$ & $\begin{array}{r}0.212 * * * * \\
(0.011)\end{array}$ & $\begin{array}{r}0.212 * * * * \\
(0.011)\end{array}$ & & & & \\
\hline$\Delta$ Foreign share & $\begin{array}{r}0.001 * * \\
(0.001)\end{array}$ & $\begin{array}{r}0.001 * * \\
(0.001)\end{array}$ & & & $\begin{array}{l}0.001 * \\
(0.001)\end{array}$ & $\begin{array}{l}0.001 * \\
(0.001)\end{array}$ & & \\
\hline$\Delta$ Backward same region & $\begin{array}{r}0.016 * * \\
(0.007)\end{array}$ & $\begin{array}{r}0.016 * * \\
(0.007)\end{array}$ & $\begin{array}{r}0.019 * * * \\
(0.007)\end{array}$ & $\begin{array}{r}0.019 * * * \\
(0.007)\end{array}$ & $\begin{array}{c}0.015 * \\
(0.008)\end{array}$ & $\begin{array}{c}0.015 * \\
(0.008)\end{array}$ & $\begin{array}{r}0.018 * * \\
(0.008)\end{array}$ & $\begin{array}{r}0.017 * * \\
(0.008)\end{array}$ \\
\hline$\Delta$ Backward other region & $\begin{array}{r}0.021 * * \\
(0.010)\end{array}$ & $\begin{array}{r}0.021 * * \\
(0.010)\end{array}$ & $\begin{array}{r}0.024 * * \\
(0.010)\end{array}$ & $\begin{array}{r}0.023 * * \\
(0.010)\end{array}$ & $\begin{array}{r}0.017 \\
(0.011)\end{array}$ & $\begin{array}{r}0.017 \\
(0.011)\end{array}$ & $\begin{array}{r}0.018 \\
(0.012)\end{array}$ & $\begin{array}{r}0.018 \\
(0.013)\end{array}$ \\
\hline$\Delta$ Horizontal same region & & $\begin{array}{r}0.000 \\
(0.001)\end{array}$ & & $\begin{array}{r}-0.001 \\
(0.001)\end{array}$ & & $\begin{array}{r}0.000 \\
(0.001)\end{array}$ & & $\begin{array}{r}0.000 \\
(0.001)\end{array}$ \\
\hline$\Delta$ Horizontal other region & & $\begin{array}{r}0.001 \\
(0.001)\end{array}$ & & $\begin{array}{r}0.000 \\
(0.001)\end{array}$ & & $\begin{array}{r}0.000 \\
(0.002)\end{array}$ & & $\begin{array}{r}0.000 \\
(0.002)\end{array}$ \\
\hline Intercept & $\begin{array}{r}-0.060^{* *} \\
(0.030)\end{array}$ & $\begin{array}{r}-0.062 * * \\
(0.031)\end{array}$ & $\begin{array}{r}-0.072 * * \\
(0.033)\end{array}$ & $\begin{array}{r}-0.074^{* *} \\
(0.033)\end{array}$ & $\begin{array}{c}-0.059^{*} \\
(0.033)\end{array}$ & $\begin{array}{c}-0.060^{*} \\
(0.034)\end{array}$ & $\begin{array}{r}-0.078 * * \\
(0.037)\end{array}$ & $\begin{array}{r}-0.080^{* *} \\
(0.038)\end{array}$ \\
\hline Year dummies & yes & yes & yes & yes & yes & yes & yes & yes \\
\hline Industry dummies & yes & yes & yes & yes & yes & yes & yes & yes \\
\hline Regional dummies & yes & yes & yes & yes & yes & yes & yes & yes \\
\hline No. of obs. & 6862 & 6853 & 5925 & 5923 & 6862 & 6853 & 5925 & 5923 \\
\hline F-stat & 42.06 & 39.96 & 38.36 & 36.35 & 2.61 & 2.44 & 2.17 & 2.10 \\
\hline Prob $>$ F & 0.00 & 0.00 & 0.00 & 0.00 & 0.00 & 0.00 & 0.00 & 0.00 \\
\hline $\mathrm{R}^{2}$ & 0.38 & 0.38 & 0.37 & 0.37 & 0.01 & 0.01 & 0.01 & 0.01 \\
\hline
\end{tabular}

Robust standard errors are listed in parenthesis. ***,**,* denote significance at the 1,5 and $10 \%$ level. 
Table 5. Regresions in First Differences. Spillovers Associated with Export- versus Domestic-market-oriented Foreign Affiliates

\begin{tabular}{|c|c|c|c|c|c|c|c|c|}
\hline \multirow[b]{3}{*}{$\Delta \ln \mathrm{L}$} & & & & & \multicolumn{4}{|c|}{ with Olley-Pakes correction } \\
\hline & \multicolumn{2}{|c|}{ All firms } & \multicolumn{2}{|c|}{ Domestic firms } & \multicolumn{2}{|c|}{ All firms } & \multicolumn{2}{|c|}{ Domestic firms } \\
\hline & $\begin{array}{r}0.373 * * * \\
(0.019)\end{array}$ & $\begin{array}{r}0.373 * * * \\
(0.019)\end{array}$ & $\begin{array}{r}0.360 * * * \\
(0.021)\end{array}$ & $\begin{array}{r}0.360 * * * \\
(0.021)\end{array}$ & & & & \\
\hline$\Delta \ln \mathrm{K}$ & $\begin{array}{r}0.040 * * * \\
(0.013)\end{array}$ & $\begin{array}{r}0.040 * * * \\
(0.013)\end{array}$ & $\begin{array}{r}0.038 * * * \\
(0.012)\end{array}$ & $\begin{array}{r}0.039 * * * \\
(0.012)\end{array}$ & & & & \\
\hline$\Delta \ln \mathrm{M}$ & $\begin{array}{r}0.213 * * * \\
(0.020)\end{array}$ & $\begin{array}{r}0.213 * * * \\
(0.020)\end{array}$ & $\begin{array}{r}0.213 * * * \\
(0.019)\end{array}$ & $\begin{array}{r}0.212 * * * \\
(0.019)\end{array}$ & & & & \\
\hline$\Delta$ Foreign share & $\begin{array}{l}0.001 * \\
(0.001)\end{array}$ & $\begin{array}{l}0.001 * \\
(0.001)\end{array}$ & & & $\begin{array}{r}0.001 * * \\
(0.001)\end{array}$ & $\begin{array}{l}0.001 * \\
(0.001)\end{array}$ & & \\
\hline$\Delta$ Backward (export-oriented) & $\begin{array}{r}0.033 * * \\
(0.013)\end{array}$ & $\begin{array}{r}0.033 * * \\
(0.013)\end{array}$ & $\begin{array}{r}0.032 * * \\
(0.013)\end{array}$ & $\begin{array}{r}0.032 * * \\
(0.013)\end{array}$ & $\begin{array}{c}0.028 * \\
(0.016)\end{array}$ & $\begin{array}{c}0.028 * \\
(0.016)\end{array}$ & $\begin{array}{c}0.028 * \\
(0.016)\end{array}$ & $\begin{array}{c}0.028 * \\
(0.016)\end{array}$ \\
\hline$\Delta$ Backward (local-market-oriented) & $\begin{array}{r}0.049 * * * \\
(0.017)\end{array}$ & $\begin{array}{r}0.050 * * * \\
(0.017)\end{array}$ & $\begin{array}{r}0.058 * * * \\
(0.017)\end{array}$ & $\begin{array}{r}0.058 * * * \\
(0.017)\end{array}$ & $\begin{array}{r}0.050 * * \\
(0.022)\end{array}$ & $\begin{array}{r}0.050 * * \\
(0.022)\end{array}$ & $\begin{array}{r}0.059 * * * \\
(0.023)\end{array}$ & $\begin{array}{r}0.059 * * \\
(0.023)\end{array}$ \\
\hline$\Delta$ Horizontal & & $\begin{array}{r}-0.001 \\
(0.002)\end{array}$ & & $\begin{array}{r}0.000 \\
(0.002)\end{array}$ & & $\begin{array}{l}-0.001 \\
(0.002)\end{array}$ & & $\begin{array}{r}0.000 \\
(0.003)\end{array}$ \\
\hline Intercept & $\begin{array}{l}-0.057 \\
(0.057)\end{array}$ & $\begin{array}{l}-0.052 \\
(0.059)\end{array}$ & $\begin{array}{l}-0.071 \\
(0.051)\end{array}$ & $\begin{array}{l}-0.071 \\
(0.052)\end{array}$ & $\begin{array}{l}-0.058 \\
(0.059)\end{array}$ & $\begin{array}{l}-0.055 \\
(0.059)\end{array}$ & $\begin{array}{l}-0.078 \\
(0.059)\end{array}$ & $\begin{array}{l}-0.080 \\
(0.058)\end{array}$ \\
\hline Year dummies & yes & yes & yes & yes & yes & yes & yes & yes \\
\hline Industry dummies & yes & yes & yes & yes & yes & yes & yes & yes \\
\hline Regional dummies & yes & yes & yes & yes & yes & yes & yes & yes \\
\hline No. of obs. & 6862 & 6862 & 5925 & 5923 & 6862 & 6862 & 5925 & 5923 \\
\hline F-stat & 56.11 & 54.57 & 43.73 & 43.28 & 3.1 & 3.01 & 2.86 & 2.93 \\
\hline Prob $>$ F & 0.00 & 0.00 & 0.00 & 0.00 & 0.00 & 0.00 & 0.00 & 0.00 \\
\hline $\mathrm{R}^{2}$ & 0.38 & 0.38 & 0.38 & 0.38 & 0.02 & 0.02 & 0.02 & 0.02 \\
\hline BK (export) diff from BK (local-mkt-or) & yes $(5 \%)$ & yes $(10 \%)$ & yes $(1 \%)$ & yes $(1 \%)$ & yes $(5 \%)$ & yes $(6 \%)$ & yes $(1 \%)$ & yes $(1 \%)$ \\
\hline
\end{tabular}

Standard errors in parenthesis have been corrected for clustering for each industry in each year. ${ }^{* * *}, * *,{ }^{*}$ denote significance at the 1,5 and $10 \%$ level. 
Table 6. Regresions in First Differences. Spillovers Associated with Fully- versus Partially-Owned Foreign Affiliates

\begin{tabular}{|c|c|c|c|c|c|c|c|c|}
\hline \multirow[b]{3}{*}{$\Delta \ln \mathrm{L}$} & & & & & \multicolumn{4}{|c|}{ with Olley-Pakes correction } \\
\hline & \multicolumn{2}{|c|}{ All firms } & \multicolumn{2}{|c|}{ Domestic firms } & \multicolumn{2}{|c|}{ All firms } & \multicolumn{2}{|c|}{ Domestic firms } \\
\hline & $\begin{array}{r}0.373 * * * \\
(0.019)\end{array}$ & $\begin{array}{r}0.373^{* * * *} \\
(0.019)\end{array}$ & $\begin{array}{r}0.360 * * * * \\
(0.021)\end{array}$ & $\begin{array}{r}0.359 * * * \\
(0.021)\end{array}$ & & & & \\
\hline$\Delta \ln \mathrm{K}$ & $\begin{array}{r}0.040 * * * \\
(0.013)\end{array}$ & $\begin{array}{r}0.040 * * * * \\
(0.013)\end{array}$ & $\begin{array}{r}0.038 * * * * \\
(0.012)\end{array}$ & $\begin{array}{r}0.039 * * * \\
(0.012)\end{array}$ & & & & \\
\hline$\Delta \ln \mathrm{M}$ & $\begin{array}{r}0.212 * * * \\
(0.020)\end{array}$ & $\begin{array}{r}0.213 * * * * \\
(0.020)\end{array}$ & $\begin{array}{r}0.212 * * * \\
(0.019)\end{array}$ & $\begin{array}{r}0.212 * * * \\
(0.019)\end{array}$ & & & & \\
\hline$\Delta$ Foreign share & $\begin{array}{r}0.001 * * \\
(0.001)\end{array}$ & $\begin{array}{r}0.001 * * \\
(0.001)\end{array}$ & & & $\begin{array}{r}0.001 * * \\
(0.001)\end{array}$ & $\begin{array}{r}0.001 * * \\
(0.001)\end{array}$ & & \\
\hline$\Delta$ Backward (fully-owned) & $\begin{array}{r}0.029 \\
(0.025)\end{array}$ & $\begin{array}{r}0.028 \\
(0.025)\end{array}$ & $\begin{array}{r}0.041 \\
(0.028)\end{array}$ & $\begin{array}{r}0.041 \\
(0.029)\end{array}$ & $\begin{array}{r}0.011 \\
(0.031)\end{array}$ & $\begin{array}{r}0.011 \\
(0.031)\end{array}$ & $\begin{array}{r}0.012 \\
(0.035)\end{array}$ & $\begin{array}{r}0.012 \\
(0.035)\end{array}$ \\
\hline$\Delta$ Backward (partially-owned) & $\begin{array}{l}0.040^{*} \\
(0.020)\end{array}$ & $\begin{array}{l}0.040^{*} \\
(0.020)\end{array}$ & $\begin{array}{l}0.037^{*} \\
(0.023)\end{array}$ & $\begin{array}{l}0.037 * \\
(0.023)\end{array}$ & $\begin{array}{r}0.034 \\
(0.025)\end{array}$ & $\begin{array}{r}0.034 \\
(0.025)\end{array}$ & $\begin{array}{r}0.033 \\
(0.028)\end{array}$ & $\begin{array}{r}0.033 \\
(0.028)\end{array}$ \\
\hline$\Delta$ Horizontal & & $\begin{array}{r}-0.001 \\
(0.002)\end{array}$ & & $\begin{array}{r}0.000 \\
(0.002)\end{array}$ & & $\begin{array}{c}-0.001 \\
(0.002)\end{array}$ & & $\begin{array}{r}0.000 \\
(0.003)\end{array}$ \\
\hline Intercept & $\begin{array}{r}-0.054 \\
(0.057)\end{array}$ & $\begin{array}{r}-0.051 \\
(0.058)\end{array}$ & $\begin{array}{r}-0.069 \\
(0.049)\end{array}$ & $\begin{array}{c}-0.071 \\
(0.050)\end{array}$ & $\begin{array}{r}-0.051 \\
(0.060)\end{array}$ & $\begin{array}{r}-0.048 \\
(0.060)\end{array}$ & $\begin{array}{r}-0.070 \\
(0.059)\end{array}$ & $\begin{array}{c}-0.072 \\
(0.059)\end{array}$ \\
\hline Year dummies & yes & yes & yes & yes & yes & yes & yes & yes \\
\hline Industry dummies & yes & yes & yes & yes & yes & yes & yes & yes \\
\hline Regional dummies & yes & yes & yes & yes & yes & yes & yes & yes \\
\hline No. of obs. & 6862 & 6862 & 5925 & 5923 & 6862 & 6862 & 5925 & 5923 \\
\hline F-stat & 53.93 & 52.17 & 40.77 & 40.96 & 3.5 & 3.41 & 2.2 & 2.19 \\
\hline Prob $>$ F & 0.00 & 0.00 & 0.00 & 0.00 & 0.00 & 0.00 & 0.00 & 0.00 \\
\hline R-squared & 0.38 & 0.38 & 0.37 & 0.37 & 0.01 & 0.01 & 0.01 & 0.01 \\
\hline BK (fully) diff from BK (part) & no & no & no & no & no & no & no & no \\
\hline
\end{tabular}

Standard errors in parenthesis have been corrected for clustering for each industry in each year. ${ }^{* * *}, * *, *$ denote significance at the 1,5 and $10 \%$ level. 


\section{Appendix}

\section{Estimation Procedure with Olley-Pakes Correction}

The semi-parametric estimation of the production function parameters suggested by Olley and Pakes (1996) is employed to account for the endogeneity of input selection by the firm.

It is assumed that at the beginning of every period a firm chooses variable factors (labor) and a level of investment, which together with the current capital value determine the capital stock at the beginning of the next period. The capital accumulation equation is given by

$k_{i t+1}=(1-\delta) k_{i t}+i_{i t}$

where $k=$ capital and $i=$ investment.

Consider the following Cobb-Douglas production function model:

$y_{i t}-m_{i t}=\alpha+\beta_{l} * l_{i t}+\beta_{k} * k_{i t}+\omega_{i t}+\eta_{i t}$

where $y_{i t}-m_{i t}=\log$ (output-materials) $=\log$ of value added, $l_{i t}=\log$ of labor, and subscripts $i$ and $t$ stand for firm and time, respectively. $\omega_{i t}$ denotes productivity, and $\eta_{i t}$ stands for either measurement error (which can be serially correlated) or a shock to productivity which is not forecastable during the period in which labor can be adjusted. Both $\omega_{i t}$ and $\eta_{i t}$ are unobserved. The difference is that $\omega_{i t}$ is a state variable in the firm's decision problem and thus affects the input demand while $\eta_{i t}$ does not. Labor is assumed to be a freely variable input. Capital is a fixed factor and is only affected by the distribution of $\omega$ conditional on information at time t-1 and past values of $\omega$.

Since the unobserved productivity shock $\omega_{i t}$ is assumed to be correlated with $k_{i t}$, the estimated coefficient $\beta_{k}$ will be biased. The insight of the method is that the observable characteristics of the firm can be modeled as a monotonic function of the productivity of the firm. Inverting such a function allows us to model the unobserved component of the productivity as a function of the observed variables, namely investment.

The investment decision depends on the capital stock and on firm productivity:

$$
i_{i t}=i_{i t}\left(\omega_{i t}, k_{i t}\right)
$$

By inverting the above equation, one can express unobserved productivity $\omega_{i t}$ as a function of observable investment and capital and thus it is possible to control for $\omega_{i t}$ in estimation. 


$$
\omega_{i t}=h_{i t}\left(i_{i t}, k_{i t}\right)
$$

By substituting (4) into (2), the equation to be estimated in the first stage of the procedure is obtained:

$y_{i t}-m_{i t}=\alpha+\beta_{l} * l_{i t}+\beta_{k} * k_{i t}+h\left(i_{i t}, k_{i t}\right)+\eta_{i t}$

The functional form of $h\left(\right.$.) is not known. Therefore, the $\beta_{k}$ coefficient cannot be estimated at this stage. A partially linear model including a third order polynomial expansion in capital and investment to approximate the form of the $h($.$) is estimated. { }^{25}$ From this stage the consistent estimate of the labor input coefficient $\left(\beta_{l}\right)$ as well as the estimate of the third order polynomial in $i_{i t}$ and $k_{i t}$ (referred to as $\psi_{\mathrm{it}}$ ) are obtained.

$\psi_{i t}=\alpha+\beta_{k} *_{i t}+h\left(i_{i t}, k_{i t}\right)$

Thus,

$h\left(i_{i t}, k_{i t}\right)=\psi_{i t}-\beta_{k}{ }^{*} k_{i t}$

The second step of the estimation procedure considers the expectation of $y_{i t+1}-m_{i t+1}$ $\beta_{l} * l_{i t+1}$

$$
\begin{aligned}
E\left[y_{i t+1}\right. & \left.-m_{i t+1}-\beta_{l} * l_{i t+1} \mid k_{i t+1}\right] \\
& =\alpha+\beta_{k} * k_{i t+1}+E\left[\omega_{i t+1} \mid \omega_{i t}\right] \\
& \equiv \beta_{k} * k_{i t+1}+g\left(\omega_{i t}\right)
\end{aligned}
$$

Assuming that $\omega_{i t}$ is serially correlated, one can rewrite $\omega_{i t+1}$ as a function of $\omega_{i t}$, letting $\xi_{i t+1}$ be the innovation in $\omega_{i t+1}$. Using (4) and (7), the above equation becomes a function of $i_{i t}$ and $k_{i t}$

$y_{i t+1}-m_{i t+1}-\beta_{l} * l_{i t+1}=\beta_{k} * k_{i t+1}+g\left(\psi_{i t}-\beta_{k} * k_{i t}\right)+\xi_{i t+1}+\eta_{i t+1}$

where $\mathrm{g}$ is a third order polynomial of $\psi_{i t}-\beta_{k}{ }^{*} k_{i t}$. This is the equation to be estimated in the second stage of the procedure. Only in this stage it is possible to obtain consistent estimates of $\beta_{k}$. Since the capital in use in a given period is assumed to be known at the beginning of the period and $\xi_{i t+1}$ is mean independent of all variables known at the beginning of the period, $\xi_{i t+1}$ is mean independent of $k_{i t+1}$. A non-linear least squares method is used to estimate the above equation.

Using the estimated coefficients, the total factor productivity is calculated as $t f p_{i t}=y_{i t}-m_{i t}-\beta_{l} * l_{i t}-\beta_{k} * k_{i t}$

25 Olley and Pakes (1996) suggest both a kernel and a series estimator, but favor the former since its limiting distribution is known. 


\section{DAVIDSON INSTITUTE WORKING PAPER SERIES - Most Recent Papers}

The entire Working Paper Series may be downloaded free of charge at: www.wdi.bus.umich.edu

CURRENT AS OF 3/27/03

\begin{tabular}{|c|c|c|}
\hline Publication & Authors & Date \\
\hline $\begin{array}{l}\text { No. 548: Does Foreign Direct Investment Increase the Productivity of } \\
\text { Domestic Firms? In Search of Spillovers through Backward Linkages }\end{array}$ & Beata K. Smarzynska & Mar. 2003 \\
\hline $\begin{array}{l}\text { No. 547: Re-employment Probabilities and Wage Offer Function for } \\
\text { Russian Labor Market }\end{array}$ & Natalia V. Smirnova & Feb. 2003 \\
\hline $\begin{array}{l}\text { No. 546: Democratization's Risk Premium: Partisan and Opportunistic } \\
\text { Political Business Cycle Effects on Sovereign Ratings in Developing } \\
\text { Countries }\end{array}$ & $\begin{array}{l}\text { Steven Block, Burkhard N. } \\
\text { Schrage and Paul M. Vaaler }\end{array}$ & Feb. 2003 \\
\hline $\begin{array}{l}\text { No. 545: Structural Reforms and Competitiveness: Will Europe } \\
\text { Overtake America? }\end{array}$ & Jan Svejnar & Feb. 2003 \\
\hline No. 544: Why the Rich May Favor Poor Protection of Property Rights & Konstantin Sonin & Dec. 2002 \\
\hline $\begin{array}{l}\text { No. 543: Reinvested Earnings Bias, The "Five Percent" Rule and the } \\
\text { Interpretation of the Balance of Payments - With an Application to } \\
\text { Transition Economies }\end{array}$ & $\begin{array}{l}\text { Josef C. Brada and Vladimír } \\
\text { Tomšík }\end{array}$ & Feb. 2003 \\
\hline $\begin{array}{l}\text { No. 542: The Impact of Ownership Reform in Chinese Industry, 1995- } \\
2001\end{array}$ & $\begin{array}{l}\text { Gary H. Jefferson, Su Jian, Jiang } \\
\text { Yuan and Yu Xinhua }\end{array}$ & Feb. 2003 \\
\hline $\begin{array}{l}\text { No. 541: Defensive and Strategic Restructuring of Firms during the } \\
\text { Transition to a Market Economy }\end{array}$ & $\begin{array}{l}\text { Domadenik, Janez Prašnikar and } \\
\text { Jan Svejnar }\end{array}$ & Feb. 2003 \\
\hline No. 540: Tenuous Financial Stability & $\begin{array}{l}\text { Neven T. Valev and John A. } \\
\text { Carlson }\end{array}$ & Feb. 2003 \\
\hline $\begin{array}{l}\text { No. 539: Non-monetary Trade and Differential Access to Credit in the } \\
\text { Russian Transition }\end{array}$ & Vlad Ivanenko & Feb. 2003 \\
\hline $\begin{array}{l}\text { No. 538: International Price-Fixing Cartels and Developing Countries: } \\
\text { A Discussion of Effects and Policy Remedies }\end{array}$ & $\begin{array}{l}\text { Margaret Levenstein and Valerie } \\
\text { Suslow with Lynda Oswald }\end{array}$ & Feb. 2003 \\
\hline No. 537: Foreign Banks in Bulgaria, 1875-2002 & $\begin{array}{l}\text { Kenneth Koford and Adrian E. } \\
\text { Tschoegl }\end{array}$ & Jan. 2003 \\
\hline $\begin{array}{l}\text { No. 536: Forthcoming in Vanderbilt Journal of Transnational Law, } \\
\text { "Healthy Organizations and the Link to Peaceful Societies: Strategies } \\
\text { for Implementing Organizational Change" }\end{array}$ & $\begin{array}{l}\text { Jeannette Jackson and Maria } \\
\text { Coolican }\end{array}$ & Jan. 2003 \\
\hline $\begin{array}{l}\text { No. 535: Forthcoming in Vanderbilt Journal of Transnational Law, } \\
\text { "Workplace Violence and Security: Are there Lessons for } \\
\text { Peacemaking?" }\end{array}$ & $\begin{array}{l}\text { Frances E. Zollers and Elletta } \\
\text { Sangrey Callahan }\end{array}$ & Jan. 2003 \\
\hline $\begin{array}{l}\text { No. 534: Forthcoming in Vanderbilt Journal of Transnational Law, } \\
\text { "700 Families to Feed: The Challenge of Corporate Citizenship" }\end{array}$ & Tara J. Radin & Jan. 2003 \\
\hline $\begin{array}{l}\text { No. 533: Forthcoming in Vanderbilt Journal of Transnational Law, } \\
\text { "Governing for Genuine Profit" }\end{array}$ & Michael J. O'Hara & Jan. 2003 \\
\hline $\begin{array}{l}\text { No. 532: Forthcoming in Vanderbilt Journal of Transnational Law, } \\
\text { "Adapting Corporate Governance for Sustainable Peace" }\end{array}$ & $\begin{array}{l}\text { Timothy L. Fort and Cindy A. } \\
\text { Schipani }\end{array}$ & Jan. 2003 \\
\hline $\begin{array}{l}\text { No. 531: Forthcoming in Vanderbilt Journal of Transnational Law, } \\
\text { "Groundings of Voice in Employee Rights" }\end{array}$ & Dana Muir & Jan. 2003 \\
\hline $\begin{array}{l}\text { No. 530: Forthcoming in Vanderbilt Journal of Transnational Law, } \\
\text { Gender Voice and Correlations with Peace }\end{array}$ & $\begin{array}{l}\text { Morehead Dworkin and Cindy A. } \\
\text { Schipani }\end{array}$ & Jan. 2003 \\
\hline $\begin{array}{l}\text { No. 529: Forthcoming in Vanderbilt Journal of Transnational Law, } \\
\text { "The Organizational Model for Workplace Security" }\end{array}$ & Dr. Thomas K. Capozzoli & Jan. 2003 \\
\hline $\begin{array}{l}\text { No. 528: Forthcoming in Vanderbilt Journal of Transnational Law, } \\
\text { "Nationbuilding 101: Reductionism in Property, Liberty, and Corporate } \\
\text { Governance" }\end{array}$ & O. Lee Reed & Jan. 2003 \\
\hline $\begin{array}{l}\text { No. 527: Forthcoming in Vanderbilt Journal of Transnational Law, "On } \\
\text { Virtue and Peace: Creating a Workplace Where People Can Flourish" }\end{array}$ & $\begin{array}{l}\text { Caryn L. Beck-Dudley and } \\
\text { Steven H. Hanks }\end{array}$ & Jan. 2003 \\
\hline $\begin{array}{l}\text { No. 526: Forthcoming in Vanderbilt Journal of Transnational Law, } \\
\text { "Novartis and the United Nations Global Compact Initiative" }\end{array}$ & Lee A. Tavis & Dec. 2002 \\
\hline $\begin{array}{l}\text { No. 525: Why Transition Paths Differ: Russian and Chinese Enterprise } \\
\text { Performance Compared }\end{array}$ & Sumon Bhaumik and Saul Estrin & Jan. 2003 \\
\hline $\begin{array}{l}\text { No. 524: Official Regulations and the Shadow Economy: A Labour } \\
\text { Market Approach }\end{array}$ & Maxim Bouev & Dec. 2002 \\
\hline
\end{tabular}

